\title{
Comparative study of perinatal outcome between abdominal and vaginal route of delivery in case of breech presentation
}

\author{
Gourav Ranjan Tripathy, M. Smitha*, Anand Acharya
}

Department of Obstetrics and Gynecology, Konaseema Institute of Medical Science, Amalapuram, Andhra Pradesh, India

Received: 10 July 2018

Accepted: 02 August 2018

*Correspondence:

Dr. M. Smitha,

E-mail: m_smitha@gmail.com

Copyright: (c) the author(s), publisher and licensee Medip Academy. This is an open-access article distributed under the terms of the Creative Commons Attribution Non-Commercial License, which permits unrestricted non-commercial use, distribution, and reproduction in any medium, provided the original work is properly cited.

\section{ABSTRACT}

Background: Breech presentation is also one of the most interesting subjects in obstetrics as no other malpresentation has so many manoeuvres during vaginal delivery and their impact on perinatal mortality. The mode of delivery also depends on so many variables like parity, type of breech presentation, associated obstetric complications, estimated birth weight etc and also from obstetrician point of view.

Methods: Pregnant mother with breech presentation of gestational age 32 weeks or more were included in this study. Multiple pregnancy with first baby in breech presentation were excluded from this study. New born baby with gross congenital anomalies like anencephaly, omphalocele were excluded from this study. The cases for present study were collected from antenatal OPD, labour room, High-risk ward and Post-natal ward of KIMS \& RF from June 2016 to December 2017.

Results: Out of 61 cases of caesarean section there were 4 cases $(6.55 \%)$ of neonatal death. PNM among the 100 cases was $4 \%$ in caesarean section. In 32 assisted breech delivery cases there were 8 cases $(25 \%)$ of perinatal death. PNM among the 100 cases was $8 \%$ in assisted breech delivery. Out of 4 cases of breech extractions there were 3 cases (75\%) of perinatal death. PNM among the 100 cases was $3 \%$ in breech extraction.

Conclusions: Present study suggests that breech delivery should preferably be always managed in the hospital by skilled and experienced obstetrician with an assistant in collaboration with a pediatrician and an anesthetist. As good numbers of babies were premature a good premature care unit should be pre-managed under the supervision of a pediatrician.

Keywords: Breech presentation, Perinatal outcome, Route of delivery

\section{INTRODUCTION}

When the podalic pole of the fetus enter the pelvis first before the any other parts, the presentation is breech. The lie is longitudinal. The term probably derives from the same word as britches, which described a cloth covering the lions and thighs. It is the commonest malpresentation.

Over the years numerous reviews on breech delivery have stressed on the morbidity and mortality of newborn mainly. Different views have been expressed regarding the factors affecting the foetal outcome and there is no unanimity of opinion regarding the management. Hall et al described it as "One of the greatest tests of obstetrics skill, the act of obstetric finding its full flower in proper handling of this problem."1 During the last 20-30 years, management of breech has therefore been somewhat controversial.

Recent years have witnessed a marked increase of caesarean section rate for the delivery of both preterm and term breech presentation. Delivery of all breech 
fetuses by caesarean section may produce with the best possible neonatal outcome but the approach overlooks the increased maternal morbidity and cost associated with caesarean delivery in the present and future pregnancy, particularly in developing countries like India. Cox presents breech delivery as a prime example of obstetric art, technique and judgment all playing their role. ${ }^{2}$

"Let me see a man conduct a breech case and I will give you his obstetric ratings" - nicely commented by De Lee (1948)..$^{3}$

Breech presentation occurs in 3-4\% of all deliveries. The percentage of breech deliveries decreases with advancing gestational age from $25 \%$ of births prior to 28 weeks gestation to $7 \%$ of births at 32 weeks gestation to $1-3 \%$ of births at term. In breech presentation it is the baby who suffers most. The principal factors contributing to these higher perinatal losses are prematurity, birth trauma, birth asphyxia, congenital malformation and intrauterine death.

Present study has been designed to study the perinatal mortality and morbidity, risk factors, morbidity and mortality according to the mode of delivery and avoidability of perinatal death.

\section{METHODS}

Present study is simple randomized cross-sectional study conducted in the department of obstetrics Konaseema institute of medical science Amalapuram from June 2016 to December 2017. During this period 100 parturients were included in this study. Parameters studied in this are age, parity, maturity of the foetus, type of breech, mode of delivery for after coming head, birth weight, congenital anomalies, Apgar score at 1 and 5 minutes and foetal anomalies.

\section{Study population}

Pregnant mother with breech presentation of gestational age 32 weeks or more were included in this study. Multiple pregnancy with first baby in breech presentation were excluded from this study. New born baby with gross congenital anomalies like anencephaly, omphalocele were excluded from this study. Term baby in this study has been defined as those who have completed 37 weeks of gestation or 2500 grms or more when LMP have unknown but clinically and radiologically appeared $>37$ weeks. When the period of gestation has less than 37 completed weeks or when the LMP have not available, babies weighing less than 2500 gms have considered as preterm breech.

\section{Statistical analysis}

The data collected on the basis of above mentioned parameters were first tabulated and analyzed by standard statistical method in consultation with department of community medicine.

\section{RESULTS}

The present study group is composed of 100 mothers with breech presentation (single term and pre-term breech deliveries, excluding birth weight less than $1000 \mathrm{gm}$, first baby in breech presentation of multiple pregnancy and gross congenital anomaly of new born) delivered in KIMS and RF, Amlapuram, between period June 2016 to December 2017.

Table 1: Aetiology of breech presentation.

\begin{tabular}{|lll|}
\hline A etiology & Total No. of cases & Percentage \\
\hline Prematurity & 27 & 27 \\
\hline IUFD & 5 & 5 \\
\hline Placenta praevia & 2 & 2 \\
\hline Hydrocephalus & 2 & 2 \\
\hline Unknown & 64 & 64 \\
\hline
\end{tabular}

As evident from Table 1 prematurity was the single most common known cause of breech presentation (27\%). Other known causes were IUFD (5\%), Placenta praevia (2\%), hydrocephalus (2\%). But aetiology was unknown in most cases (64\%).

Table 2: Route and mode of delivery of the cases.

\begin{tabular}{|lll|}
\hline Mode of delivery & $\begin{array}{l}\text { No. of cases } \\
(\mathrm{N}=100)\end{array}$ & $\begin{array}{l}\text { Percentage } \\
(\%)\end{array}$ \\
\hline Caesarean section & 61 & 61 \\
\hline Assisted breech delivery & 32 & 32 \\
\hline Breech extraction & 4 & 4 \\
\hline $\begin{array}{l}\text { Spontaneous breech } \\
\text { delivery }\end{array}$ & 3 & 3 \\
\hline
\end{tabular}

Out of 100 cases, 61 cases (61\%) were delivered by caesarean section. Percentage of other mode of deliveries were assisted breech delivery, breech extraction and spontaneous breech delivery were $32 \%, 4 \%$ and $3 \%$ respectively. Out of 100 cases, total 39 cases (39\%) were delivered vaginally.

Table 3: Analysis of cases having spontaneous breech delivery.

\begin{tabular}{|llll|}
\hline \multirow{4}{*}{ Gravida } & Primi & 0 & 0 \\
\cline { 2 - 4 } & Multi & 3 & 100 \\
\hline \multirow{2}{*}{$\begin{array}{l}\text { Immediate } \\
\text { foetal } \\
\text { outcome }\end{array}$} & Living & 1 & 33.33 \\
\cline { 2 - 4 } & Death & 2 & 66.66 \\
\cline { 2 - 4 } $\begin{array}{l}\text { Duration of } \\
\text { pregnancy }\end{array}$ & b. Post-partum & 1 & 50 \\
\hline
\end{tabular}

Out of 3 cases of spontaneous breech deliveries $100 \%$ (3) cases were multigravida and $100 \%$ (3) cases were in unbooked series. All the cases were pre-term deliveries 
$(100 \%)$. Immediate foetal outcome was poor, only $33.33 \%$ (1) case was born alive.

Table 4: Analysis of cases delivered vaginally by assisted breech delivery.

\begin{tabular}{|c|c|c|c|}
\hline & & No. & $\%$ \\
\hline \multirow{3}{*}{$\begin{array}{l}\text { Type of } \\
\text { breech }\end{array}$} & Frank & 16 & 50 \\
\hline & Flexed & 14 & 43.75 \\
\hline & Footling & 2 & 6.25 \\
\hline \multirow{2}{*}{ Gravida } & Primi & 9 & 28.12 \\
\hline & Multi & 23 & 71.87 \\
\hline \multirow{5}{*}{$\begin{array}{l}\text { Immediate } \\
\text { foetal } \\
\text { outcome }\end{array}$} & Healthy & 17 & 53.12 \\
\hline & Asphyxiated & 8 & 25.0 \\
\hline & Still birth & 4 & 9.37 \\
\hline & a. Antepartum & 3 & 66.66 \\
\hline & b. Intra Partum & 1 & 33.33 \\
\hline \multirow{3}{*}{$\begin{array}{l}\text { Duration } \\
\text { of } \\
\text { pregnancy }\end{array}$} & Below 37 weeks & 9 & 28.12 \\
\hline & $\begin{array}{l}\text { Between } 37 \text { and } 42 \\
\text { completed weeks }\end{array}$ & 22 & 68.75 \\
\hline & $\begin{array}{l}\text { Above } 42 \text { completed } \\
\text { weeks }\end{array}$ & 1 & 3.12 \\
\hline
\end{tabular}

Out of 32 cases the percentage distribution of assisted breech delivery in primipara and multipara were $28.12 \%$ and $71.87 \%$ respectively. The immediate foetal outcome was good $(53.12 \%) 17$ cases. The percentage distribution of pre-term, term and post-term cases were $28.12 \%$, $68.75 \%$ and $3.12 \%$ respectively.

Table 5: Analysis of mode of delivery of after coming head of cases having assisted vaginal breech delivery.

\begin{tabular}{|llll|} 
Gravida & $\begin{array}{l}\text { M.S.V. No. } \\
\text { of cases } \\
(\%)\end{array}$ & $\begin{array}{l}\text { B.M. No. of } \\
\text { cases }(\%)\end{array}$ & $\begin{array}{l}\text { Forceps No. } \\
\text { of cases } \\
(\%)\end{array}$ \\
\hline Primi (9) & $3(33.33 \%)$ & $5(55.55 \%)$ & $1(11.11 \%)$ \\
\hline Multi $(23)$ & $8(34.78 \%)$ & $13(56.52 \%)$ & $2(8.69 \%)$ \\
\hline Healthy $(17)$ & $6(54.54 \%)$ & $9(60 \%)$ & $2(66.66 \%)$ \\
\hline $\begin{array}{l}\text { Asphyxiated } \\
(8)\end{array}$ & $3(27.27 \%)$ & $4(22.22 \%)$ & $1(33.33 \%)$ \\
\hline Stillbirth (4) & $2(18.18 \%)$ & $2(11.11 \%)$ & $0(0.0 \%)$ \\
\hline Total & 11 & 15 & 3 \\
\hline
\end{tabular}

M.S.V. : Mauriceau Smellie Veit method ,B.M. : Burns Marshall technique.

Table 6: Indication and outcome of cases having breech extraction by vaginal route under anaesthesia.

\begin{tabular}{|c|c|c|c|c|}
\hline Indication & $\begin{array}{l}\text { No. of } \\
\text { cases }\end{array}$ & $\begin{array}{l}\text { Foetal } \\
\text { outcome }\end{array}$ & No. & $\begin{array}{l}\% \text { of } \\
\text { death }\end{array}$ \\
\hline \multirow{2}{*}{$\begin{array}{l}\text { Cord } \\
\text { prolapse }\end{array}$} & \multirow{2}{*}{$2(50 \%)$} & Live birth & 1 & \multirow{4}{*}{75} \\
\hline & & IUFD & 1 & \\
\hline $\begin{array}{l}\text { Antepartum } \\
\text { haemorrhage }\end{array}$ & $1(25 \%)$ & $\begin{array}{l}\text { Intrapartum } \\
\text { death }\end{array}$ & 1 & \\
\hline $\begin{array}{l}\text { Foetal } \\
\text { distress }\end{array}$ & $1(25 \%)$ & $\begin{array}{l}\text { Immediate } \\
\text { neonatal } \\
\text { death }\end{array}$ & 1 & \\
\hline
\end{tabular}

Out of 32 cases of assisted vaginal breech delivery after coming head of breech was managed by M.S.V. method in 11 cases $(34.37 \%)$, Burns Marshall technique in 18 cases $(56.28 \%)$ and forceps in 3 cases $(9.37 \%)$.

Table 7: Analysis of cases of caesarean section in breech presentation.

\begin{tabular}{|llll|}
\hline \multirow{2}{*}{ Gravida } & Primi & $\begin{array}{l}\text { No. of } \\
\text { cases }\end{array}$ & $\begin{array}{l}\text { Percentage } \\
(\%)\end{array}$ \\
\cline { 2 - 4 } & Multi & 42 & 68.85 \\
\hline $\begin{array}{l}\text { Immediate } \\
\text { foetal out } \\
\text { come }\end{array}$ & Healthy & 52 & 31.14 \\
\hline & Asphyxiated & 9 & 85.24 \\
\cline { 2 - 4 } & Stillbirth & 0 & 14.75 \\
\hline \multirow{2}{*}{$\begin{array}{l}\text { Duration } \\
\text { of } \\
\text { pregnancy }\end{array}$} & $\begin{array}{l}\text { 37 - } 37 \text { weeks } \\
\text { weeks }\end{array}$ & 11 & 0.0 \\
\cline { 2 - 4 } & $\begin{array}{l}>41 \\
\text { completed } \\
\text { weeks }\end{array}$ & 5 & 18.03 \\
\hline & & & 73.77 \\
\hline
\end{tabular}

Out of 32 cases of assisted breech delivery immediate foetal outcome was better in forceps delivery $(66.66 \%)$. And regarding perinatal loss, the forceps delivery of after coming head of breech seems to be best $(0.0 \%)$. Foetal injury was occurred by BM in 3 cases -2 brachial plexus injury and 1 fracture femur.

Table 8: Perinatal death in complicated breech presentations, according to route of delivery.

\begin{tabular}{|c|c|c|c|}
\hline $\begin{array}{l}\text { Route of } \\
\text { delivery }\end{array}$ & No. of cases & $\begin{array}{l}\text { No. of } \\
\text { perinatal } \\
\text { death }\end{array}$ & $\begin{array}{l}\text { Percentage } \\
(\%)\end{array}$ \\
\hline $\begin{array}{l}\text { Caesarean } \\
\text { section }\end{array}$ & $61(93.84 \%)$ & 4 & 6.55 \\
\hline $\begin{array}{l}\text { Vaginal } \\
\text { delivery }\end{array}$ & $4(6.15 \%)$ & 3 & 75 \\
\hline
\end{tabular}

Out of 39 vaginal breech deliveries, breech extraction was needed in only 4 cases $(4 \%)$.

The commonest indication was cord prolapse (50\%), the other indications were antepartum hemorrhage (25\%), foetal distress (25\%). Breech extraction was associated with Perinatal death 3 cases $(75 \%)$ out of 4 cases.

Out of 100 cases, caesarean section was done in 61 cases (61\%). Distribution of caesarean section in primi and multi were $68.85 \%$ and $31.14 \%$ respectively.

The immediate foetal outcome was very good, $85.24 \%$ healthy. The percentage distribution of caesarean section in preterm, term and post term pregnancy were $18.03 \%$, $73.77 \%$ and $8.19 \%$ respectively. 
Table 9: Outcome of babies of birth weight more than 3000 gms according to route of delivery.

\begin{tabular}{|c|c|c|c|c|c|c|c|}
\hline \multirow[b]{2}{*}{ Group } & \multirow[b]{2}{*}{$\begin{array}{l}\text { Total No. of } \\
\text { cases }\end{array}$} & \multicolumn{3}{|c|}{ Caesarean section } & \multicolumn{3}{|c|}{ Vaginal delivery } \\
\hline & & $\begin{array}{l}\text { No. of } \\
\text { cases }\end{array}$ & $\begin{array}{l}\text { No. of } \\
\text { perinatal } \\
\text { death }\end{array}$ & Percentage & No. of cases & $\begin{array}{l}\text { No. of } \\
\text { perinatal } \\
\text { death }\end{array}$ & Percentage \\
\hline $\begin{array}{l}\text { Between } \\
\text { 3001-3500gm }\end{array}$ & $15(24.59 \%)$ & $13(86.6 \%)$ & 0 & 0.0 & $2(13.33 \%)$ & 1 & 50 \\
\hline$>3500 \mathrm{gm}$ & $10(16.39 \%)$ & $9(90 \%)$ & 0 & 0.0 & $1(\%)$ & 1 & 100 \\
\hline
\end{tabular}

Table 10: Analysis of babies in relation to their birth weight and mode of deliveries.

\begin{tabular}{|llllll}
\hline Birth weight in gms & Total cases $(\%)$ & $\begin{array}{l}\text { Caesarean } \\
\text { section }(\%)\end{array}$ & $\begin{array}{l}\text { Vaginal delivery } \\
\text { Assisted breech } \\
\text { delivery }\end{array}$ & $\begin{array}{l}\text { Spontaneous } \\
\text { breech delivery }\end{array}$ & $\begin{array}{l}\text { Breech } \\
\text { extraction }\end{array}$ \\
\hline$<2000$ & $11(11 \%)$ & $2(18.18 \%)$ & $5(45.45 \%)$ & $2(18.18 \%)$ & $2(18.18 \%)$ \\
\hline $2001-2500$ & $15(15 \%)$ & $9(60 \%)$ & $4(26.66 \%)$ & $1(6.66 \%)$ & $1(6.66 \%)$ \\
\hline $2501-3000$ & $49(49 \%)$ & $28(57.14 \%)$ & $20(40.8 \%)$ & $0(0 \%)$ & $1(2.04 \%)$ \\
\hline $3001-3500$ & $15(15 \%)$ & $13(86.66 \%)$ & $2(13.3 \%)$ & $0(0 \%)$ & $0(0 \%)$ \\
\hline$>3500$ & $10(10 \%)$ & $9(90 \%)$ & $1(10 \%)$ & $0(0 \%)$ & $0(0 \%)$ \\
\hline
\end{tabular}

Table 11: Outcome of low birth weight babies weighing less than 2000 gms according to route of delivery.

\begin{tabular}{|lllllll|}
\hline $\begin{array}{l}\text { Total no. of } \\
\text { cases }\end{array}$ & \multicolumn{2}{l}{ Caesarean section } & & \multicolumn{2}{l}{ Vaginal delivery } \\
\hline & $\begin{array}{l}\text { Total No. of } \\
\text { cases }\end{array}$ & $\begin{array}{l}\text { Total No. of } \\
\text { perinatal death }\end{array}$ & Percentage & $\begin{array}{l}\text { Total No. of } \\
\text { cases }\end{array}$ & $\begin{array}{l}\text { Total No. of } \\
\text { perinatal death }\end{array}$ & Percentage \\
\hline $11(11 \%)$ & $2(18.18 \%)$ & 1 & 50 & $9(81.81 \%) 1$ & 7 & 77.77 \\
\hline
\end{tabular}

Table 12: Incidence of perinatal death in relation to birth weight of babies.

\begin{tabular}{|lllllll|} 
Group & $\begin{array}{l}\text { Birth weight of } \\
\text { babies (gms) }\end{array}$ & $\begin{array}{l}\text { Total } \\
\text { delivery }\end{array}$ & $\begin{array}{l}\text { Perinatal } \\
\text { death }(\%)\end{array}$ & $\begin{array}{l}\text { Antepartum } \\
\text { death }(\%)\end{array}$ & $\begin{array}{l}\text { Intrapartum } \\
\text { death }(\%)\end{array}$ & $\begin{array}{l}\text { Neonatal } \\
\text { death }(\%)\end{array}$ \\
\hline 1 & $<2000$ & $11(11 \%)$ & $8(72.7 \%)$ & $2(25 \%)$ & $0(0 \%)$ & $6(75 \%)$ \\
\hline 2 & $2000-2500$ & $15(15 \%)$ & $5(33.3 \%)$ & $0(0 \%)$ & $1(20 \%)$ & $4(80 \%)$ \\
\hline 3 & $2501-3000$ & $49(49 \%)$ & $2(4.08 \%)$ & $1(50.0 \%)$ & $0(0 \%)$ & $1(50.0 \%)$ \\
\hline 4 & $3001-3500$ & $15(15 \%)$ & $1(6.66 \%)$ & $1(100.0 \%)$ & $0(0 \%)$ & $0(0 \%)$ \\
\hline 5 & $>3500$ & $10(10 \%)$ & $1(10 \%)$ & $0(0 \%)$ & $1(100.0 \%)$ & $0(0 \%)$ \\
\hline
\end{tabular}

Table 13: Analysis of outcome of different types of breech in relation to route of delivery.

\begin{tabular}{|llllllll|}
\hline $\begin{array}{l}\text { Type of } \\
\text { Breech }\end{array}$ & $\begin{array}{l}\text { Total No. } \\
\text { of cases }\end{array}$ & $\begin{array}{l}\text { Caesarean section } \\
\text { Total no. of } \\
\text { cases }\end{array}$ & $\begin{array}{l}\text { Total no. } \\
\text { death }\end{array}$ & Percentage & $\begin{array}{l}\text { Vaginal Delivery } \\
\text { Total no. of } \\
\text { cases }\end{array}$ & $\begin{array}{l}\text { Total no. } \\
\text { death }\end{array}$ & Percentage \\
\hline Frank & $51(51 \%)$ & $34(66.6 \%)$ & 2 & 5.88 & $17(33.33 \%)$ & 5 & 29.41 \\
\hline Flexed & $36(36 \%)$ & $18(50 \%)$ & 1 & 5.55 & $18(50 \%)$ & 6 & 33.33 \\
\hline Footling & $13(13 \%)$ & $9(69.23 \%)$ & 1 & 11.11 & $4(30.76 \%)$ & 2 & 50 \\
\hline
\end{tabular}

Table 14: Incidence of perinatal death in relation to gestational age.

\begin{tabular}{|llllll|}
\hline $\begin{array}{l}\text { Gestational age } \\
\text { (weeks) }\end{array}$ & $\begin{array}{l}\text { Total no. of } \\
\text { cases }\end{array}$ & $\begin{array}{l}\text { Total no. of } \\
\text { perinatal death }\end{array}$ & $\begin{array}{l}\text { Antepartum } \\
\text { death }(\%)\end{array}$ & $\begin{array}{l}\text { Intrapartum } \\
\text { death }(\%)\end{array}$ & $\begin{array}{l}\text { Neonatal death } \\
(\%)\end{array}$ \\
\hline$<37$ & $27(27 \%)$ & $11(40.7 \%)$ & $2(18.18 \%)$ & $1(9.09 \%)$ & $8(72.72 \%)$ \\
\hline Between 37 to 41 & $67(67 \%)$ & $5(7.46 \%)$ & $2(40 \%)$ & $0(0 \%)$ & $3(60 \%)$ \\
\hline$>41$ & $6(6 \%)$ & $1(16.6 \%)$ & $0(0 \%)$ & $1(100.0 \%)$ & $0(0 \%)$ \\
\hline Total & 100 & $17(17 \%)$ & $4(23.52 \%)$ & $2(11.76 \%)$ & $11(64.70 \%)$ \\
\hline
\end{tabular}


Out of 4 cases $(6.15 \%)$ of vaginal delivery in complicated breech perinatal death was $75 \%$. In contrast perinatal death in 61 cases of caesarean section was $6.55 \%$.

Out of 15 cases $(24.59 \%)$ of birth weight between 3001 3500 gms, 13 cases $(86.6 \%)$ had caesarean section and 2 cases $(13.33 \%)$ delivered vaginally. Perinatal death in relation to route of delivery was $0 \%$ and $50 \%$. Among the 10 cases of estimated weight over 3500 gms, 9 cases (90\%) had caesarean section and 1 case (10\%) had vaginal delivery. Perinatal death in caesarean section group and vaginal delivery group were $0 \%$ and $100 \%$ respectively. There were 11 cases $(11 \%)$ of babies having birth weight of less than 2000 gm, of which 2 cases
(18.18\%) had caesarean section and 5 cases $(45.45 \%)$ had assisted breech delivery, 2 case (18.18\%) spontaneous breech delivery and 2 cases $(18.18 \%)$ had breech extraction.

In the group 2, percentage distribution of caesarean section, assisted breech delivery, spontaneous breech delivery and breech extraction were $60 \%, 26.66 \%$, $6.66 \%, 6.66 \%$ respectively.

In the group 3, percentage distribution of caesarean section, assisted breech delivery, spontaneous breech delivery and breech extraction were $57.14 \%, 40.8 \%, 0 \%$, $2.04 \%$ respectively. Group 4 and Group 5 were discussed in Table 9.

Table 15: Perinatal death in relation to route and mode of delivery.

\begin{tabular}{|llllll|}
\hline Total cases & $\begin{array}{l}\text { Total no. of } \\
\text { perinatal death }\end{array}$ & $\begin{array}{l}\text { Antepartum } \\
\text { death }(\%)\end{array}$ & $\begin{array}{l}\text { Intrapartum } \\
\text { death }(\%)\end{array}$ & $\begin{array}{l}\text { Post partum } \\
\text { death }(\%)\end{array}$ & $\begin{array}{l}\text { Percentage } \\
\text { Caesarean section 61(61\%) }\end{array}$ \\
\hline Assisted breech delivery 32 (32\%) & 8 & $0(0 \%)$ & $0(0 \%)$ & $4(100 \%)$ & 6.55 \\
\hline Breech extraction 4 (4\%) & 3 & $3(37.5 \%)$ & $1(12.5 \%)$ & $4(50 \%)$ & 25.0 \\
\hline Spontaneous breech delivery 3(3\%) & 2 & $1(33.33 \%)$ & $1(33.33 \%)$ & $1(33.33 \%)$ & 75.0 \\
\hline
\end{tabular}

Table 16: Incidence of perinatal death in relation to mode of delivery of after coming head in assisted breech delivery.

\begin{tabular}{|lllllll|}
\hline $\begin{array}{l}\text { Mode of } \\
\text { delivery }\end{array}$ & $\begin{array}{l}\text { Total No. of } \\
\text { cases }\end{array}$ & $\begin{array}{l}\text { Perinatal death } \\
\text { Antepartum } \\
\text { death (\%) }\end{array}$ & $\begin{array}{l}\text { Intrapartum } \\
\text { death (\%) }\end{array}$ & $\begin{array}{l}\text { Postpartum } \\
\text { death (\%) }\end{array}$ & Total death Percentage \\
\hline MSV & $11(34.37 \%)$ & $1(9.09 \%)$ & $1(9.09 \%)$ & $2(18.18 \%)$ & 4 & 36.36 \\
\hline BM & $18(56.25 \%)$ & $2(11.11 \%)$ & $0(0 \%)$ & $2(11.11 \%)$ & 4 & 22.22 \\
\hline Forceps & $3(9.37 \%)$ & $0(0 \%)$ & $0(0 \%)$ & $0(0 \%)$ & 0 & 0.00 \\
\hline
\end{tabular}

In this series there were 11 cases $(11 \%)$ whose birth weight was less than 2000 gms. Out of these 2 cases $(18.18 \%)$ were delivered by caesarean section and 9 cases $(81.81 \%)$ delivered vaginally. Perinatal death in these two groups of deliveries was $50 \%$ and $77.77 \%$ respectively.

In the group 1 i.e., weight of the baby below 2000 gms out of the 11 cases there were $8(72.7 \%)$ cases of perinatal death, in which percentage distribution of antepartum, intrapartum, and neonatal death were $25 \%$, $0.0 \%, 75 \%$ respectively.

In group 2 , there were 15 cases $(15 \%)$ out of which 5 $(33.3 \%)$ were perinatal death. Percentage distribution of antepartum, intrapartum and neonatal death were $0.0 \%$, $20 \%$ and $80 \%$ respectively. In group 3, there were only 2 $(4.08 \%)$ cases of perinatal death among 49 cases. Out of this $50 \%$ were antepartum and $50 \%$ neonatal death, showed best foetal outcome.

In the group 4 , there was 1 case $(6.66 \%)$ of perinatal death among 15 cases. In the group 5, there was $1(10 \%)$ perinatal death among 4 cases. The incidence of perinatal death in Frank type of breech in caesarean section and vaginal delivery were $5.88 \%$ and $29.41 \%$ respectively.

In flexed type of breech the perinatal death in caesarean section and vaginal delivery were $5.55 \%$ and $33.33 \%$ respectively. So caesarean section should be preferable to vaginal delivery in respect to perinatal death.

In footling type of breech the Perinatal death in caesarean section and vaginal delivery were $11.11 \%$ and $50 \%$ respectively. So, caesarean section should be done in footling presentation. Out of 100 cases of breech presentation maximum perinatal death were in preterm group $(40.7 \%)$ and minimum perinatal death in term group $(7.46 \%)$.

Out of total 17 cases $(17 \%)$ the perinatal death were maximum in neonatal period i.e. 11 cases $(64.70 \%)$. Out of 61 cases of caesarean section there were 4 cases $(6.55 \%)$ of neonatal death. PNM among the 100 cases was $4 \%$ in caesarean section. In 32 assisted breech delivery cases there were 8 cases $(25 \%)$ of perinatal 
death. PNM among the 100 cases was $8 \%$ in assisted breech delivery. Out of 4 cases of breech extractions there were 3 cases $(75 \%)$ of perinatal death. PNM among the 100 cases was $3 \%$ in breech extraction.

Out of 3 cases of spontaneous breech delivery there were 2 cases $(66.6 \%)$ of perinatal death. PNM among the 100 cases was $2 \%$ in spontaneous breech delivery. The incidence of perinatal death in MSV, BM and Forceps were $36.36 \%, 22.22 \%$ and $0.00 \%$ respectively. Here appear forceps caused less perinatal death than BM and MSV.

\section{DISCUSSION}

The present study of breech presentation has been carried out at KIMS and RF Amlapuram from June 2016 to December 2017. The cases have been studied with special reference to route of delivery and perinatal mortality, morbidity.

\section{Aetiology of breech presentation}

No definite aetiology of breech presentation was discovered in about $64 \%$ of cases in this series. In the remaining $36 \%$ of cases, prematurity, intrauterine foetal death, hydrocephalus and placenta praevia formed the aetiological factors. Westgreen $M$ et al showed that one group of persistent breech presentation. ${ }^{4}$ Sorensen et al stated that $15 \%$ singleton present as breech at 32 weeks. ${ }^{5}$ In this series, $27 \%$ breech deliveries occurred at less than 37 weeks. Intrauterine foetal death is known to favour breech presentation. In this series this factor was present in $5 \%$ cases.

\section{Parity}

Among 100 cases of breech presentation 52\% cases (52) were primigravida, $48 \%$ cases (48) were multigravida. Varoius author has quoted different figures Johnson et al quoted $38 \%$, and Gupta et al quoted $61.4 \% .^{6,7}$

\section{Route of delivery}

In present study percentage of caesarean section were $61 \%$ (61) and vaginal delivery were $39 \%$ (39).

\section{Mode of vaginal delivery}

In the present series, among 100 cases 39 cases were allowed vaginal delivery.

From the Table 3 it was evident that spontaneous breech delivery occurred rarely $(3 \%)$, in pre-term delivery $(100 \%)$.

In multipara mother with poor outcome of $33.3 \%$. So, spontaneous breech deliveries are never desirable in mature and even in premature breech. Authors have found from the present series that forceps should be advocated as it was associated with $0.0 \%$ perinatal mortality.

Regarding anaesthesia during second stage of labour, local perineal infiltration of pudendal block was practiced. Chandra YC et al in his series of 643 cases, shown that with epidural analgesia increased need for augmentation of labour with oxytocin, longer duration of labour and increase likelihood of caesarean section in the second stage in primipara. ${ }^{8}$ Bingham $\mathrm{P}$ et al also shown the increased duration of second stage with the use of epidural anaesthesia. ${ }^{9}$

\section{Place of caesarean section}

In passing of years, there has been a gradual rise of caesarean section rate in this presentation. COX et al found $5.6 \%$, Lyons et al found $48.3 \%$ and Jeffrey E. Green found $94 \% .^{2,10,11}$ In this series, out of 100 breech cases 61 cases $(61 \%)$ were delivered by caesarean section.

From the table $6,68.8 \%$ of the caesarean section deliveries were done in primigravida mother. This was probably due to their untested pelvis. From the Table 10, it was evident that there was a distinct correlation between birth weight of babies and mode of delivery. Out of 11 cases $(11 \%)$, whose birth weights were less than $2000 \mathrm{gm}$, incidence of caesarean section was only $18.1 \%$ ( 2 cases). When we consider the type of breech incidence of caesarean section in footling breech presentation was $69.2 \%$.

\section{Perinatal mortality / morbidity}

The gross perinatal mortality in present series was $17 \%$. Hall, Kohl (1956)1reported $30 \%$ and Gimovsky et al reported $8.5 \% .^{12}$

The following factors affected the increased perinatal mortality

\section{Maturity of the foetus}

Pre-term and premature delivery were a significant factor in high perinatal mortality associated with breech presentation. $27(27 \%)$ cases were pre-term delivery, of which perinatal death occurred in 11 cases (40.7\%). It was evident that perinatal mortality was maximum in preterm delivery.

Kauplia $\mathrm{O}$ showed that the primary cause of high perinatal death in pre-term breech was due to complication of prematurity per se $(25 \%)$ whereas the commonest cause of term breech was due to congenital abnormalities (32\%). ${ }^{13}$

Bodmer B et al showed that caesarean section rate for pre-term breech had increased from $8 \%$ to $49 \% .^{14}$ However, in our series the current trend of caesarean 
section rate in pre-term group was not followed because of lack of well-equipped neonatal care units as expected if such an attempt would be taken.

\section{Birth weight of the baby}

There is a strong correlation between perinatal mortality and low birth weight infant.

Perinatal mortality was maximum in the LBW babies. Out of 11 cases, perinatal death was 8 cases $(72.7 \%)$ and perinatal mortality declined with increasing birth weight due to careful assessment of causes for route of delivery. One case of birth weight more than $3500 \mathrm{gm}$ died due to difficult vaginal delivery. So, it is evident that caesarean section should be employed when the foetal weight is assessed $3500 \mathrm{gm}$, or more to avoid the risk of foetopelvic disproportion. Out of 11 cases of birth weight below 2000 gm, 9 cases $(81.8 \%)$ were delivered vaginaly and Perinatal death was $77.7 \%$ ( 7 cases). In Mirchandani's series (1973)15, 67.1\% of foetal loss occurred in baby of birth weight below 2250 gm. ${ }^{15}$

\section{Type of breech presentation}

In the present series, there were $36(36 \%)$ flexed breech, $51(51 \%)$ frank breech and 13(13\%) footling breech. Perinatal death in flexed and footling breech were higher following vaginal delivery than caesarean section $(22.2 \%)$ vs $(5.5 \%)$ and $(50 \%)$ vs $(11.0 \%)$ respectively.

\section{Mode of Delivery}

Vaginal delivery was associated with higher rate of perinatal death in the present series. Assisted breech delivery with or without application of forceps to the after coming head $32 \%$ cases resulted with gross perinatal death of $25 \%$ (8 cases) whereas $61 \%$ cases of caesarean section was associated with gross perinatal death of $6.55 \%$ (4 cases). Perinatal mortality among the 100 cases were $8 \%$ and $4 \%$ respectively. Regarding perinatal mortality among the 100 cases of breech presentation perinatal death in caesarean section was 4 (total caesarean section-61) and in vaginal breech delivery was 13 (total vaginal breech delivery-39). Regarding perinatal morbidity (among the 100 cases of breech delivery perinatal death-17, perinatal morbidity-12 and healthy$71)$ in caesarean section perinatal morbidity was 5 (healthy-52) and in vaginal breech delivery it was 7 (healthy-19). This is supported by the work of De Lee et al. ${ }^{3}$

\section{Mode of delivery for the after coming head}

De Lee et al, stated that most birth injuries could be avoided if application of forceps to the after-coming head was practiced routinely. ${ }^{3}$

Milner RD advocated routine forceps application in all breech deliveries. ${ }^{15}$ Forceps is preferred to nuchal traction, as it ensures a controlled delivery for the head.It was evident that the perinatal mortality was lowest in forceps group and were higher in other two.

\section{CONCLUSION}

Vaginal breech delivery requires an experienced obstetrician and careful counseling of the parent(s). Although studies on the delivery of the preterm breech are limited, the recent multicentric term breech trial found an increased rate of perinatal mortality and serious immediate perinatal morbidity.

Present study suggests that breech delivery should preferably be always managed in the hospital by skilled and experienced obstetrician with an assistant in collaboration with a pediatrician and an anesthetist. As good numbers of babies were premature a good premature care unit should be pre-managed under the supervision of a pediatrician.

Funding: No funding sources Conflict of interest: None declared

Ethical approval: The study was approved by the Institutional Ethics Committee

\section{REFERENCES}

1. Hall JE, Kohl SG. Breech presentation. A study of 1456 cases. Am J Obstet Gynaecol. 1956;72:977-90.

2. Cox LW, Chalmers TA, The effect of pre-eclamptic toxaemia on the exchange of sodium in the body and the transfer of sodium across the placenta, measured by na24 tracer methods J. Obstet Gynaecol Brit. 1950;57(62):197.

3. De Lee, JB, Green H, J.P. Principles and practice obstetrics. $1950.10^{\text {th }}$ Edn.

4. Westgren M, Edvall H, Nordström L, Svalenius E, Ranstam J. Spontaneous cephalic version of breech presentation in the last trimester. BJOG: An Int J Obstet Gynaecol. 1985;92(1):19-22.

5. Bano S, Chaudhary V, Pande S, Mehta VC, Sharma Soernes T, et al. The length of the human umbilical cord in vertex and breech presentations. Am J Obstet Gynecol. 1986 May 1;154(5):1086-7.

6. Johnson CE. Breech presentation at term. Am J Obst Gynecol. 1970;106(6):865-71.

7. Gupta PK, Gupta AP. Perinatal mortality. Indian Pediatr. 1984;22:201-5.

8. Chadha YC, Mahmood TA, Dick MJ, Smith NC, Campbell DM, Templeton A. Breech delivery and epidural analgesia. BJOG: An Int J Obstet Gynaecol. 1992;99(2):96-100.

9. Bingham P, Hird V, Lilford RJ. Management of the mature selected breech presentation: an analysis based on the intended method of delivery. BJOG: Int J Obstetr Gynaecol. 1987 Aug;94(8):746-52.

10. Lyons ER, Papsin FR. Cesarean section in the management of breech presentation. Am J Obstetr Gynecol. 1978 Mar 1;130(5):558-61. 
11. Green JE, McLean F, Smith LP, Usher R. Has an increased cesarean section rate for term breech delivery reduced the incidence of birth asphyxia, trauma, and death? Am J Obstet Gynecol. 1982 Mar 15;142(6):643-8.

12. Marti L. Gimovsky, Roger L. Wallace, Barry S. Schifrin, M.D. Richard H. Paul, MD. Randomized management of the nonfrank breech presentation at term: A preliminary report. Am J Obstet Gynecol 1983;146(1);34.

13. Kuppila O. The perinatal mortality in breech delivery and observation on affecting factors. a retrospective study of 2277 cases. Acta Obstet Gynaecol Scand. 1975;39:1-79.

14. Bodmer B, Benjamin A, Frances H. Mclean, and Robert H. Has use of cesarean section reduced the risks of delivery in the preterm breech presentation? Am J. Obstet Gynecol. 1986;154:244-50.

15. Milner, RDG. Neonatal mortality of breach delivery with and without forcep of after coming head (1975): Br J Obst Gynae. 1975;82(10);783-5.

Cite this article as: Tripathy GR, Smitha M,

Acharya A. Comparative study of perinatal outcome between abdominal and vaginal route of delivery in case of breech presentation. Int $\mathbf{J}$ Reprod Contracept Obstet Gynecol 2018;7:3758-65. 